\title{
Postnatal Development of Membrane Properties of Layer I Neurons in Rat Neocortex
}

\author{
Fu-Ming Zhou and John J. Hablitz \\ Neurobiology Research Center and Department of Physiology and Biophysics, University of Alabama at Birmingham, \\ Birmingham, Alabama 35294
}

\begin{abstract}
Using whole-cell patch-clamp techniques in brain slices, we studied the postnatal development of electrophysiological properties of rat neocortical layer I neurons during the first three weeks of postnatal life. Neurons, including CajalRetzius cells, were visualized under Nomarski optics before recording.

In the first postnatal week, all layer I neurons, including Cajal-Retzius cells, had low resting membrane potentials $(-40$ to $-55 \mathrm{mV}$ ), high input resistances (1-5 G $\Omega$ ), and long membrane time constants (80-130 msec). Action potentials (APs) of layer I neurons early in postnatal development were lower in amplitude and longer in duration. The threshold for APs also was more depolarized than in older neurons. A medium afterhyperpolarization already was present at postnatal day 0 (PNO),
\end{abstract}

but fast afterhyperpolarizations were not seen until PN10. At all postnatal ages, layer I neurons were capable of repetitive firing, displayed little or no frequency adaptation, and did not display slow afterhyperpolarizations. Early in development, layer I neurons had a prominent hyperpolarization-activated depolarizing sag that decreased with age.

These results suggest that the membrane properties of rat neocortical layer I neurons mature rapidly during the first two postnatal weeks. Cajal-Retzius cells had electrical properties similar to other layer I neurons and did not show an earlier maturation of membrane properties.

Key words: action potentials; Cajal-Retzius cell; cortical development; ion channels; interneurons; layer I neurons; membrane properties
Neurons in the rat cerebral cortex can be classified broadly as pyramidal and nonpyramidal. The former are projection cells that send axons out of the cortex or to distant targets, whereas the latter are local-circuit neurons. The postnatal development of the anatomical and electrophysiological properties of pyramidal cells in the rat cerebral cortex has been studied extensively (McCormick and Prince, 1987; Miller, 1988; Lorenzon and Foehring, 1993; Kasper ct al., 1994a,b,c). Although morphological and immunocytochemical studies have provided some information on postnatal changes in nonpyramidal cells (Meyer and FerresTorres, 1984; Miller, 1988; Van Eden et al., 1989; Del Rio et al., 1994), the ontogenesis of intrinsic membrane properties of cerebral cortical interneurons has not been studied.

Layer I of the neocortex resides just under the pial surface. Throughout postnatal development, it is the thinnest of cortical layers, less than $50 \mu \mathrm{m}$ thick at postnatal day 0 (PN0) and $\sim 150$ $\mu \mathrm{m}$ wide in the adult rat. It has a low neuronal density compared with other layers (Peters and Yilmaz, 1993). Recently, we have characterized the action potential (AP) and repetitive firing properties of mature rat neocortical layer I neurons and the underlying ionic mechanisms (Zhou and Hablitz, 1994). We found that layer I neurons fire APs typical for cortical inhibitory interneurons (Connors and Gutnick, 1990). Immunocytochemical studies have demonstrated that a majority of the intrinsic layer I cclls are $\gamma$-aminobutyric acid-positive or GABAergic, both early in development and in the adult (Gabbott and Somogyi, 1986; Van Eden et al., 1989; Winer and Larue, 1989; Del Rio et al., 1994; Imamoto

Received Aug. 21, 1995; revised Oct. 26, 1995; accepted Nov. 2, 1995.

This work was supported by National Institute of Neurological Disorders and Stroke Grant NS22373. We thank Alison Benson for excellent technical assistance.

Correspondence should be addressed to John $\mathbf{J}$. Hablitz at the above address.

Copyright 1996 Society for Neuroscicnce $0270-6474 / 96 / 161131-09 \$ 05.00 / 0$ et al., 1994; Li and Schwark, 1994; Prieto et al., 1994a,b). Layer I cells, therefore, provide a useful model system for examining developmental changes in intrinsic membrane properties of neocortical GABAergic interneurons.

Layer I neurons, particularly the Cajal-Retzius cells, have been suggested to play a role in early corticohistogenesis (MarinPadilla, 1984, 1988; Ogawa et al., 1995). The Cajal-Retzius cells are thought to differentiate very early and achieve maturity before birth (Bradford et al., 1978; Marin-Padilla, 1984; Chun and Shatz, 1989; Jacobson, 1991). Smaller neurons are incorporated into layer I during the postnatal period of cortical development and mature later. Physiological evaluation of the properties of CajalRetzius cells, however, is lacking. The present experiments were performed to characterize the basic membrane properties of rat neocortical layer I neurons, including Cajal-Retzius cells, during early postnatal life. The results indicate that all layer I neurons have immature membrane properties during the first few days of postnatal life and that these properties mature rapidly in the first two postnatal weeks.

Some preliminary results of this work have appeared in abstract form (Zhou and Hablitz, 1995).

\section{MATERIALS AND METHODS}

Slice preparation and whole-cell patch recording. Timed-pregnant SpragueDawley dams were maintained in our animal facility from embryonic day 15 (E15) until birth. All animals were housed and handled according to approved guidelines. PN0 was designated as the day of birth. Pups (PN0-PN21) were decapitated, and their brains were placed in ice-cold physiolngical saline immediately after dissection. Brain slices (150-250 $\mu \mathrm{m}$ thick) were prepared from frontal and parietal areas (Paxinos and Watson, 1986) using a vibratome and placed into an incubation chamber for at least $1 \mathrm{hr}$ before use. Individual slices were transferred to a chamber mounted on the stage of a modified Zeiss Standard microscope for recording (Thornwood, NY). 


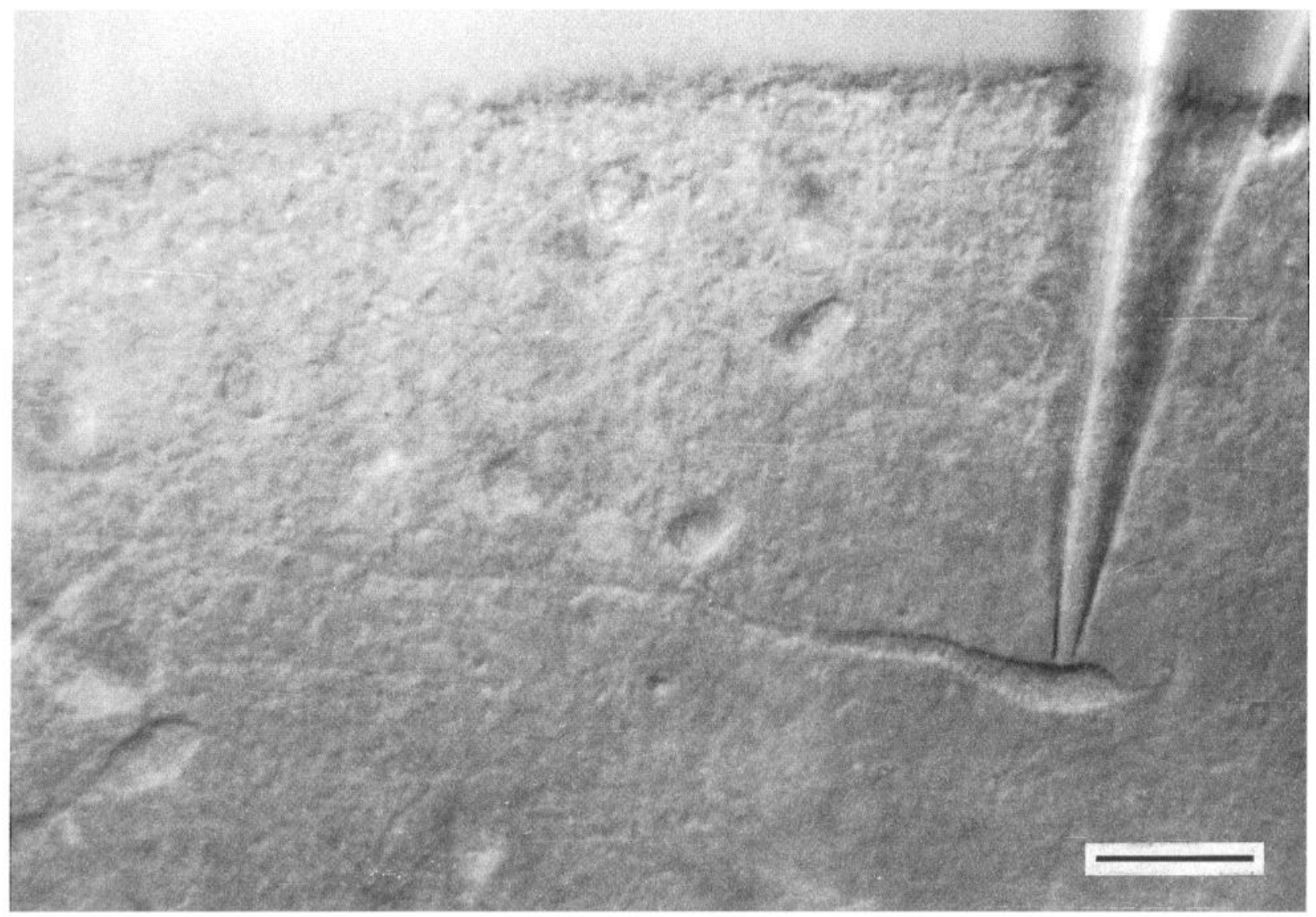

Figure 1. Photomicrograph of a neocortical brain slice from a PN7 rat. A patch pipette approaching a Cajal-Retzius cell with a typical horizontal bipolar appearance is shown. The pial surface is seen at the top of the photograph. At this age, Cajal-Retzius cells already have started to decline in number. Scale bar, $20 \mu \mathrm{m}$.

A $40 \times$ water immersion lens with $1.9 \mathrm{~mm}$ working distance (Zeiss) and differential interference contrast Nomarski optics were used to visualize individual cells before recording (Edwards et al., 1989). Neurons in layer I were identified based on distance below the pial surface (visible at the top of Fig. 1), and Cajal-Retzius cells were recognized by their horizontal orientation. An example of a typical layer I Cajal-Retzius cell being recorded is shown in Figure 1. Cell identity was verified by intracellular labeling with biocytin (Zhou and Hablitz, 1995). All recordings were obtained at room temperature $\left(21-23^{\circ} \mathrm{C}\right)$. The chamber was perfused at a rate of 3-4 ml/min with a physiological saline containing (in $\mathrm{mM}$ ): 125 $\mathrm{NaCl}, 3.5 \mathrm{KCl}, 2.5 \mathrm{CaCl}_{2}, 1.3 \mathrm{MgCl}_{2}, 26 \mathrm{NaHCO}_{3}$, and 10 D-glucose. The solution was bubbled continuously with $95 \% \mathrm{O}_{2} / 5 \% \mathrm{CO}_{2}$ to maintain a $\mathrm{pH}$ of 7.4 .

Procedures to obtain whole-cell recordings (Hamill et al., 1981) were similar to those described by Edwards et al. (1989), except that a cleaning step was not used. Patch pipettes were pulled from borosilicate capillary tubing (KG-33 glass, $1.5 \mathrm{~mm}$ outside diameter, $1.12 \mathrm{~mm}$ inside diameter; Garner Glass, Claremont, CA) using a Narishige PP-83 (Narishige, Japan) electrode puller. These pipettes had resistances of 2-4 M $\Omega$ when filled with the following solution (in $\mathrm{mm}$ ): $125 \mathrm{~K}$-gluconate, $10 \mathrm{KCl}, 10$ HEPES, $2 \mathrm{Mg}$-ATP, $0.2 \mathrm{Na}$-GTP, and 0.5 or 0.2 EGTA. $\mathrm{pH}$ was adjusted to 7.3 with $\mathrm{KOH}$. Osmolarity was adjusted to $280-290 \mathrm{mOsm}$. Electrical signals were amplified and low-pass-filtered at $5 \mathrm{kHz}$ with an Axopatch 200 amplifier (Axon Instruments, Foster City, CA). The series resistance between the amplifier and the cell interior was between 3 and $12 \mathrm{M} \Omega$ and could not be compensated in current-clamp mode. However, the currents used were usually $<200 \mathrm{pA}$, causing a voltage error of $<2 \mathrm{mV}$.

After the whole-cell recording mode was established, the resting membrane potential of the cell was recorded. Neurons then were held at approximately $-60 \mathrm{mV}$ in current-clamp mode by passing, if necessary, steady DC currents. Current-voltage relationships were assessed by recording responses to a series of hyperpolarizing and depolarizing current pulses. Repetitive firing properties were studied by applying suprathresh- old current pulses of varying intensity and duration. Voltage signals were digitized on-line and analyzed off-line using pClamp software (Axon Instruments)

\section{RESULTS \\ Developmental changes in passive membrane properties}

Although layer I neurons are anatomically heterogeneous, no significant difference in electrophysiological properties among layer I neurons with different morphological features was noted at any of the ages examined. Therefore, the results from different cell types were pooled for analysis. In the PN0-PN9 period, many layer I neurons were unable to generate APs or fired only lowamplitude, broad APs after depolarizing current injection. These cells were judged to have been injured during the sectioning and/or patching procedures, although it is possible that some of these cells were degenerating. Such cells were excluded from the analysis.

Resting membrane potential (RMP) was measured shortly after establishing whole-cell recording mode. In the first few postnatal days, the RMP of layer I neurons was quite depolarized ( -40 to $-50 \mathrm{mV}$; Fig. 2A). Despite this depolarized RMP, spontaneous APs were observed only rarely, indicating a relatively more depolarized AP threshold. RMP became progressively more negative with age. Starting around PN9 the rate of change began to decline, and from PN13 forward values for RMP stabilized; further increases in RMP were not observed (Fig. 2A). 

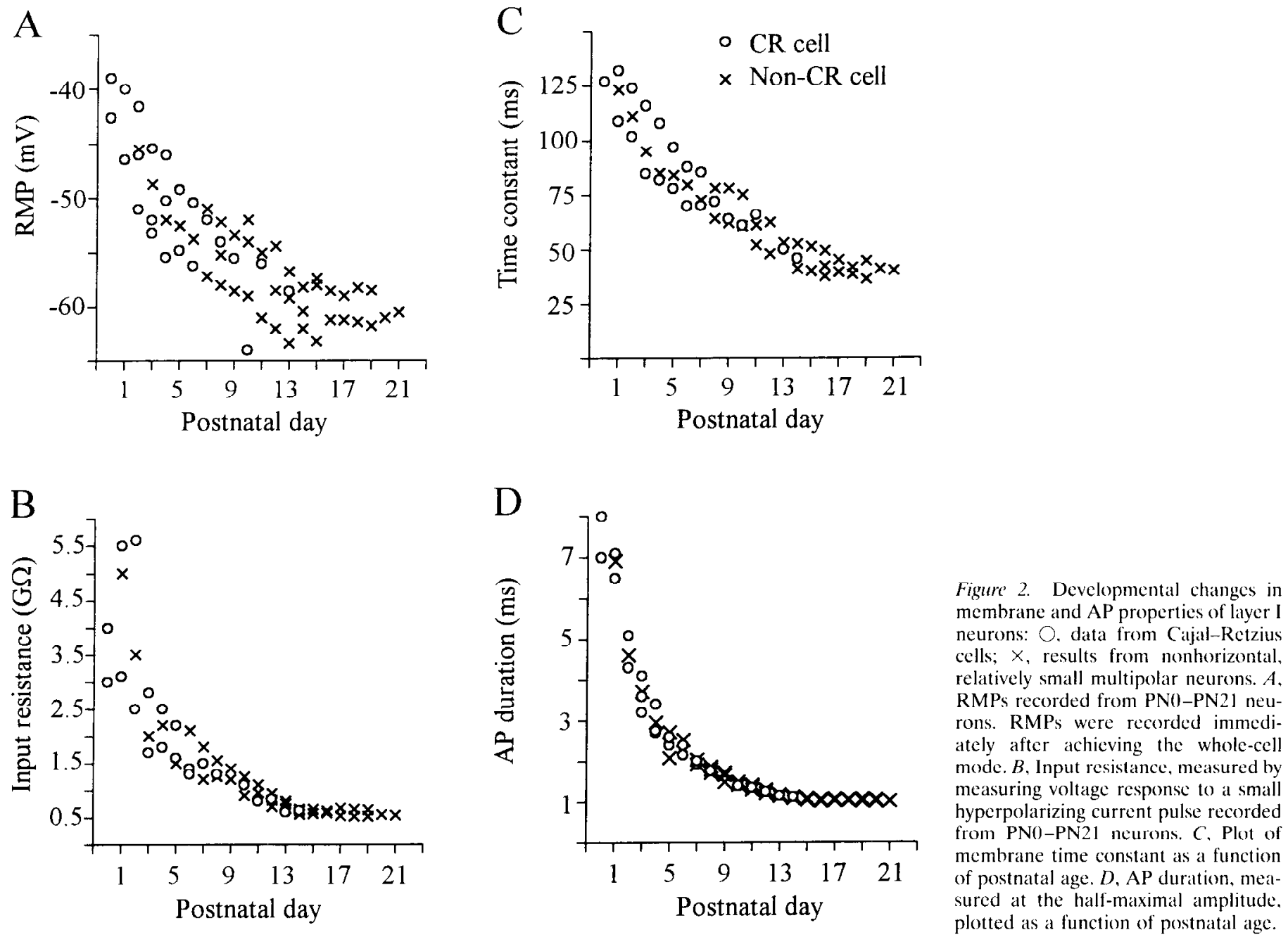

Input resistance $\left(R_{\mathrm{N}}\right)$ was calculated, using Ohm's law, from the voltage response to a small hyperpolarizing current pulse (usually -10 to $-20 \mathrm{pA}$ ) from an RMP or holding potential of approximately $-60 \mathrm{mV}$. These measurements were made over a narrow range of membrane potentials around $-60 \mathrm{mV}$ to avoid distortion by activation of voltage-dependent conductances (Spruston and Johnston, 1992). As shown in Figure $2 B, R_{\mathrm{N}}$ in cells in the PN0-PN5 age period was very high, usually $2000-3000 \mathrm{M} \Omega$, and in three cells exceeded $5000 \mathrm{M} \Omega . R_{\mathrm{N}}$ declined rapidly with age, particularly in the first postnatal week. At PN13, $R_{\mathrm{N}}$ already had declincd to $-700 \mathrm{M} \Omega$. In the third postnatal week, $R_{\mathrm{N}}$ slowly decreased further to an average value near $600 \mathrm{M} \Omega$ (Fig. $2 B$ ).

Estimates of the membrane time constant $\tau$ were obtained by fitting the voltage transient induced by a small, hyperpolarizing current injection to an exponential function. We found that in all cells from PN0-PN21 neurons $(n=56)$, the following doubleexponential function gave the best fits: $A_{1} \times \exp \left(-t / \tau_{0}\right)+A_{2} \times$ $\exp \left(-t / \tau_{1}\right)+C$, where $\tau_{0}$ represents the longest or somatic membrane time constant $\left(\tau=\tau_{0}\right)$ and $\tau_{1}$ represents a shorter equalizing time constant depending on neuron geometry such as the attaching dendritic tree (Rall, 1977). As shown in Figure $2 C, \tau_{0}$ often was $>100 \mathrm{msec}$ in the very young cells and decreased to $\sim 50$ msec after PN13.

From the obtained $\tau_{0}$, we also estimated the specific membrane resistance, $R_{\mathrm{m}}$, assuming that the specific membrane capacitance $C_{\mathrm{n}}$ is $1 \mu \mathrm{F} / \mathrm{cm}^{2}$ and does not change during development, accord- ing to the relation: $\tau_{0}=R_{\mathrm{m}} \times C_{\mathrm{m}} . R_{\mathrm{m}}$ was calculated to be $\sim 100$ $\mathrm{K} \Omega / \mathrm{cm}^{\prime}$ in PN0-PN4 cells. $R_{\mathrm{m}}$ declined quickly and was only $\sim 50$ $\mathrm{K} \Omega / \mathrm{cm}^{2}$ around PN13. However, subsequent decreases in $R_{\mathrm{m}}$ after this point were quite slow and modest (Fig. 2B). The dendritic $R_{\mathrm{m}}$ has been suggested to be different from the somatic $R_{\mathrm{m}}$ (Pongracz et al., 1991). Estimates of $\tau_{1}$ were quite variable depending on the fitting interval and could not be used to estimate the dendritic $R_{\mathrm{m}}$. This may be because $\tau_{1}$ represents a summation of multiple dendritic charging components (Rall, 1977).

\section{Development of AP waveform and repetitive firing behavior}

In this study, APs were evoked by intracellular injection of depolarizing current pulses. Layer I neurons were capable of repetitive firing at the earliest stage examined (PNO). AP properties were not correlated with morphology. No significant differences between Cajal-Retzius cells and other neurons were observed. AP parameters matured rapidly during first 10 postnatal days and reached adult values between PN13 and PN21 (Fig. 2D).

\section{Single $A P S$}

After we established whole-cell recording mode, APs could be evoked in all cells. APs could be blocked by bath application of 0.5 $\mu \mathrm{M}$ tetrodotoxin (TTX), which suggests involvement of voltagedependent sodium channels. However, many PN()-PN6 neurons showed a decline in $R_{\mathrm{N}}$ and became unresponsive within $10 \mathrm{~min}$. 
A PN 1

Figure 3. Recordings of APs in layer $\mathbf{I}$ neurons at different postnatal ages. $A$, PN1 Cajal-Retzius neuron: APs are low in amplitude $(\sim 45 \mathrm{mV})$ and long in duration ( $7 \mathrm{msec}$ at half-amplitude). In this cell, an mAHP ( $\square$ ) was present. In very young cells, AP broadening was accompanied by an amplitude enhancement, perhaps because of the involvement of a calcium current. $B$, APs from a PN5 multipolar ncuron. AP amplitude has in creased, whereas the duration has decreased. A prominent $\mathrm{mAHP}$ is present, but no clear fAHP is observed. $C, A P s$ from a PN10 Cajal-Retzius neuron. Amplitude is $83 \mathrm{mV}$, duration is $1.4 \mathrm{msec}$, and both $\mathrm{AAHP}\left(\swarrow^{\prime}\right)$ and $\mathrm{mAHP}(\varpi)$ are present. $D$, APs from a PN14 smallstellate neuron. Amplitude was $95 \mathrm{mV}$, and duration was $1.1 \mathrm{msec}$. In this cell, an fADP $(\downarrow)$ partly masks the fAHP. fADP is seen only in a third of the cells $\mathrm{PN} 13$ or older.

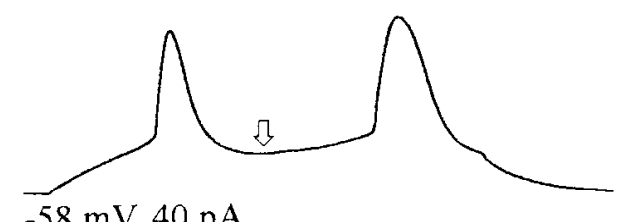

$-58 \mathrm{mV}, 40 \mathrm{pA}$

$\mathrm{C}$

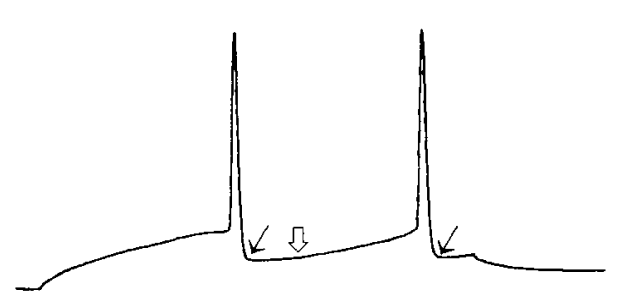

$-64 \mathrm{mV}, 40 \mathrm{pA}$
B

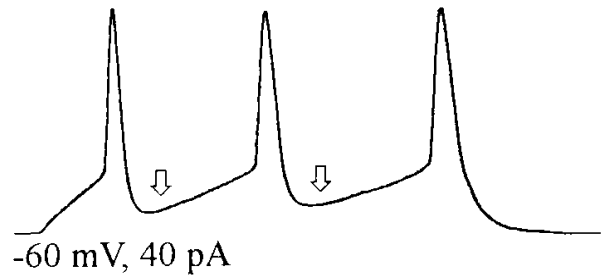

$40 \mathrm{mV}$
$40 \mathrm{~ms}$

D PN 14

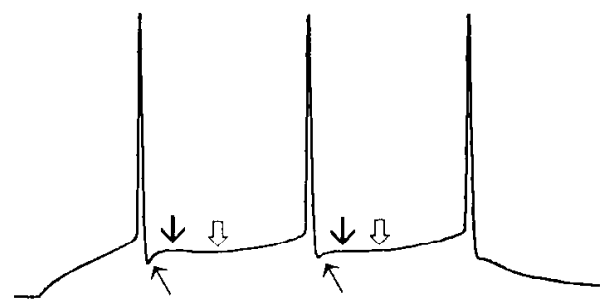

$-63 \mathrm{mV}, 40 \mathrm{pA}$
The following results are based on recordings obtained before any sign of decline. Examples of APs recorded in PN1, PN5, PN10, and PN14 neurons are shown in Figure 3. The PN1 neuron was a Cajal-Retzius cell. It had an RMP of approximately $-42 \mathrm{mV}$ and was held at $-58 \mathrm{mV}$ with steady hyperpolarizing current. A depolarizing current pulse evoked two APs at a threshold of approximately $-35 \mathrm{mV}$, which was more depolarized than that of older neurons (below $-40 \mathrm{mV}$; see below and Zhou and Hablitz, 1994). The duration of the first AP was $\sim 7 \mathrm{msec}$, measured at half-maximal amplitude, and the amplitude was $\sim 45 \mathrm{mV}$ from the threshold to the peak. The $10-90 \%$ rise and repolarization times were 2.2 and $7 \mathrm{msec}$, respectively. The amplitude and the duration of the second AP were significantly larger and longer, respectively, than those of the first one (Fig. $3 A$ ). This was seen often in young cells and was in contrast to older cells, in which AP broadening was accompanied by a reduction in amplitude (Zhou and Hablitz, 1994). A fast afterhyperpolarization (fAHP) was absent in very young cells, but a medium afterhyperpolarization (mAHP) was observed in PN1 neurons as indicated in Figure $3 A(\varpi)$. APs from a PN5 multipolar neuron are shown in Figure $3 B$. The AP threshold was still high (approximately $-36 \mathrm{mV}$ ), but AP amplitude had increased to $70 \mathrm{mV}$. The duration was shorter $(2.7 \mathrm{msec}$ at half-maximal amplitude), and the $10-90 \%$ risc and repolarization times decreased to 1.2 and $2.5 \mathrm{msec}$, respectively. mAHPs were also present $(\diamond)$. Examples of APs from a PN10 Cajal-Retzius cell are illustrated in Figure $4 C$. For the first of the two APs, the amplitude from threshold to peak was $83 \mathrm{mV}$, the half-amplitude duration was $1.4 \mathrm{msec}$, and the $10-90 \%$ rise and repolarization times were 0.6 and $1.44 \mathrm{msec}$, respectively. Therefore, the AP waveform suggests that layer I neurons at this age have acyuired the basic features of older layer I neurons (see below and Zhou and Hablitz, 1994). As shown in Figure $3 C$, by the middle of the second postnatal week, AP threshold was similar to that in older layer I neurons (Zhou and Hablitz, 1994), and prominent fAHPs $(\measuredangle)$, which clearly distinguish layer I neurons from pyramidal cells in mature neocortex (Zhou and Hablitz, 1994), were clearly identifiable. mAHPs $(\bullet)$ were still present and overlapped with fAHPs.
APs from PN14 and older neurons resembled neurons in mature neocortex, as shown in Figure 3D. This PN14 multipolar neuron had an RMP of $-63 \mathrm{mV}$. A $40 \mathrm{pA}$ depolarizing current pulse evoked three APs at a threshold of $-42 \mathrm{mV}$. The APs resembled those of mature layer I neurons, except that fAHPs appeared to be smaller in amplitude, caused partially by an overlapping fast afterdepolarization ( $\triangle \wedge D P ; \downarrow$ ). In this cell, the AP amplitude had grown to $95 \mathrm{mV}$, the half-amplitude duration had decreased to $1.1 \mathrm{msec}$, and the $10-90 \%$ rise and repolarization times were 0.54 and $1.2 \mathrm{msec}$, respectively. The fADP was seen in approximately one-third of older (PN13-PN21) layer I neurons and overlapped with and partly masked fAHPs and mAHPs.

\section{Repetitive firing properties}

Developmental changes in repetitive firing properties of layer I neurons were investigated by injecting a series of long-duration (500-1500 msec) depolarizing current pulses of varying amplitude. Repetitive firing could be evoked in PN1 neurons, including Cajal-Retzius cells, as shown in Figure $4 A$. Firing frequency increased as a function of injected current. However, cell deterioration was observed when large-amplitude current pulses were used. APs evoked by the long duration current pulses were relatively small in amplitude and long in duration. However, despite the immature AP waveform, little spike frequency adaptation was observed. Slow afterhyperpolarizations (sAHPs) were not seen. The record in Figure $4 B$ was from a PN5 multipolar neuron. The $A P s$ were briefer and higher in amplitude than those of the PN1 neuron. Adaptation was very limited, and no SAHP was observed. Repetitive firing properties of a PN10 Cajal-Retzius cell are illustrated in Figure $4 C$. The APs were briefer than those of the PN1 and PN5 neurons. The amplitude of APs also increased significantly. fAHPs followed each AP, and frequency adaptation was absent. Repetitive firing in this and other PN10 neurons closely resembled that observed in the third postnatal week. Repetitive firing in a PN16 multipolar neuron is shown in Figure $4 D$. fAHPs, which were more prominent when the firing rate was low, followed each AP. There was little or no firing adaptation, 
A

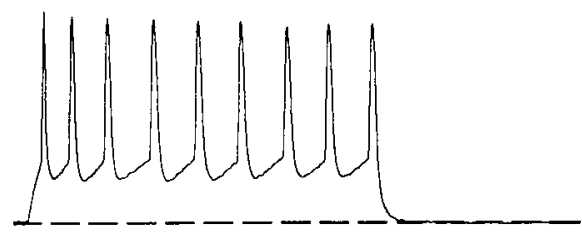

$-55 \mathrm{mV}, 30 \mathrm{pA}$

$\mathrm{C}$

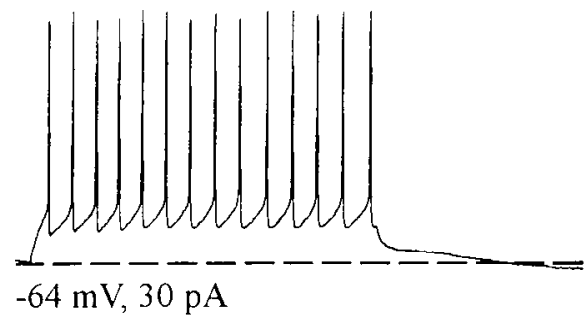

B

PN 5

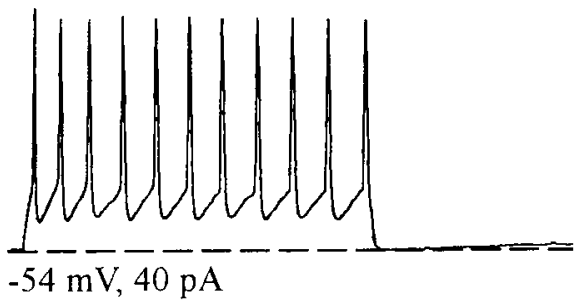

D PN 16

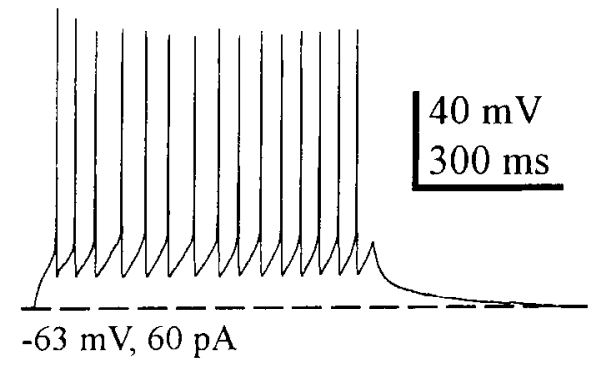

Figure 4. Development of repetitive firing properties in layer I neurons. Depolarizing current pulses evoked repetitive firing in neurons from all ages. Recordings from Cajal-Retzius cells are shown in $A$ and $C$. Specimen records in $B$ and $D$ were obtained from multipolar cells. Calibration shown in $D$ applies to all records. and sAHPs were not observed. These properties are typical for mature layer I ncurons (Zhou and I Iablitz, 1994) and nonpyramidal fast-spiking neurons in deeper cortical layers (McCormick et al., 1985). These results suggest that, at the earliest postnatal ages tested, layer I neurons have acquired features of the fastspiking bchavior typical of mature interneurons.

\section{Development of rebound excitation}

Rebound excitation in layer I neurons was studied at different ages by examining responses at the offset of long-duration $(500-$ $1000 \mathrm{msec}$ ) hyperpolarizing current pulses. Figure $5 \mathrm{~A}$ shows the results of such an experiment in a PN1 Cajal-Retzius cell. The neuron was held at $-57 \mathrm{mV}$, and hyperpolarizing current pulses of increasing amplitude were injected. After termination of the current pulse, the membrane potential overshot the holding level, which is indicative of rebound excitation. This rebound excitation increased with larger current pulses. When the rebound excitation was of sufficient magnitude, short-duration, full-size APs were triggered. Similar responses recorded from a PN14 multipolar layer I neuron are shown in Figure $5 B$. As in the PN1 neuron, rebound excitation followed the termination of the current pulse, and fast, full-size APs were triggered when the slow excitation was strong enough. Although rebound excitation was prominent in neurons from all age groups, differences in the threshold for the initiation of fast, full-size APs changed with development. The threshold was $-36 \mathrm{mV}$ for the PN1 neuron and $-46 \mathrm{mV}$ for the PN14 neuron. These changes in threshold parallel those observed for APs elicited by depolarizing current pulses.

Rebound APs were not evoked in the presence of $0.5 \mu \mathrm{M}$ TTX $(n=5)$. In two cells recorded during TTX application, rebound APs were blocked by TTX, whereas the slow rebound depolarization was mostly unaffected. This suggests that the voltagedependent, fast sodium channels responsible for APs are not involved in the slow rebound depolarization. When the cells were held at more negative potentials, rebound APs were not triggered.

\section{Developmental changes of hyperpolarization-activated current}

During passage of strong, hyperpolarizing current pulses, voltage responses were noted to reach a peak and decline or "sag" back toward the resting level. This sag was investigated by intracellular injection of long-duration $(500-1200 \mathrm{msec})$ hypcrpolarizing current pulses at different ages, as illustrated in Figure 6. The sag was seen in both Cajal-Retzius cells and other types of neurons. In PN0-PN9 neurons in layer I, sag was very prominent (Fig. 6A,B). Inspection of the specimen records in Figure $6, A$ and $B$, indicated that the sag began to activate around $-75 \mathrm{mV}$ and became very prominent around $-100 \mathrm{mV}$. Current-voltage plots of peak and steady-state voltages indicated that they started to deviate around $-80 \mathrm{mV}$ in the PN2 and PN6 neurons. From both the records and

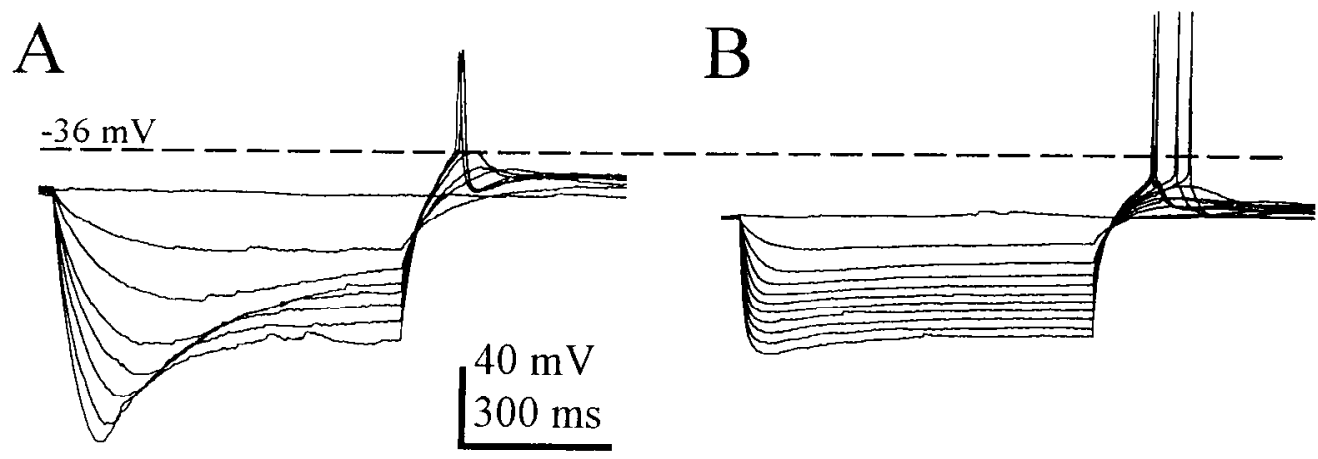

Figure 5. Rebound excitation in layer I neurons. $A$, PN1 Cajal-Retzius cell. Holding potential $-57 \mathrm{mV} . B$, PN14 multipolar neuron. Holding potential was $-65 \mathrm{mV}$. Records from the two cells are aligned by the membrane potential. Slow rebound excitations were present in both cells. The threshold for the full-size APs was approximately $-36 \mathrm{mV}$ for the PN1 cell and approximately $-50 \mathrm{mV}$ for the PN14 cell. 
A
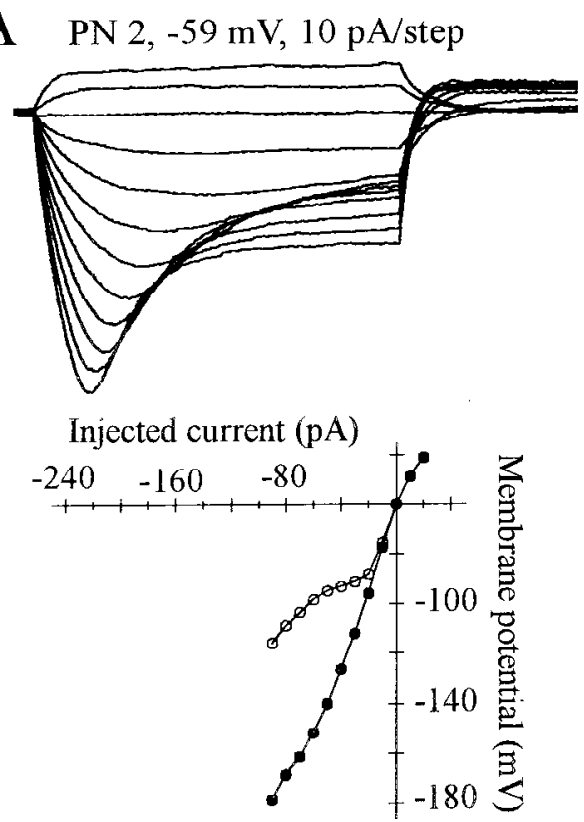

C PN 10,-66 mV, $10 \mathrm{pA} / \mathrm{step}$

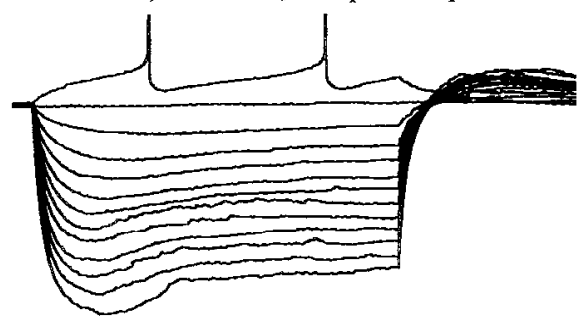

Figure 6. Developmental changes in inward rectification in layer I neurons. $A-D$, Current-voltage relationships in neurons of different ages. $A, B$, CajalRetzius cells. $C, D$, Non-Cajal-Retzius cells. Top portion in each panel shows voltage responses to a series of current pulses. The peak and steady-state voltage changes were measured and plotted against the injected current in the bottom portion. APs in $C$ and $D$ are truncated.

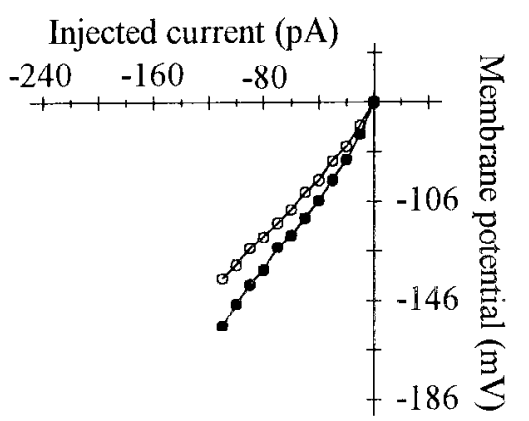

B PN 6, -60 mV, $20 \mathrm{pA} / \mathrm{step}$
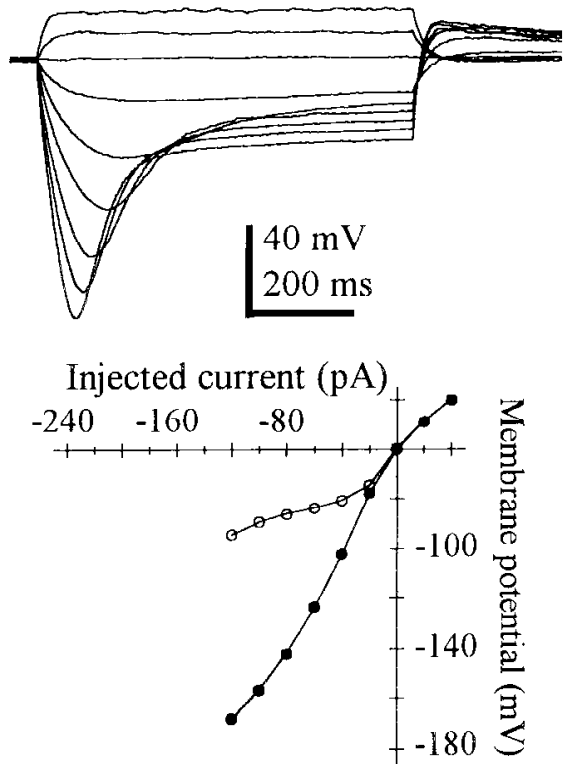

D PN 15,-66 mV, $20 \mathrm{pA} / \mathrm{step}$

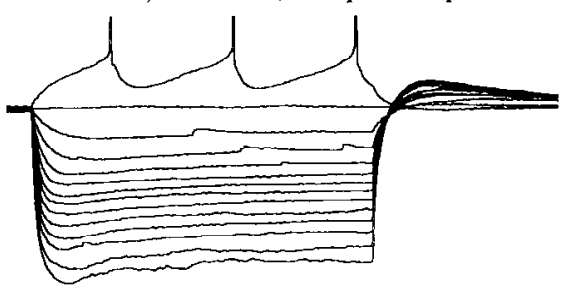

Injected current $(\mathrm{pA})$

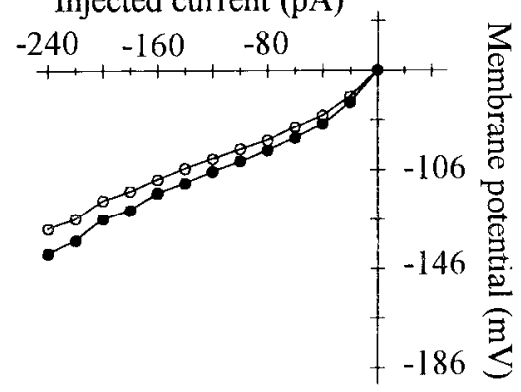

the plots, it is clear that in these very young layer I neurons the hyperpolarization-activated sag response was very pronounced. After the first postnatal week, the sag response began to decline rapidly and the peak and steady-state voltages were similar (Fig. $6 C$ ). In the third postnatal week, the sag was quite small (Fig. 6D). In all cells tested from PN6 to PN15 $(n=8)$, the sag was blocked effectively by $1 \mathrm{~mm}$ extracellular $\mathrm{Cs}^{+}$.

\section{DISCUSSION}

Using whole-cell patch-clamp techniques combined with direct visualization of neurons in a brain slice preparation, we have studied the postnatal development of the electrophysiological properties of the enigmatic layer I neurons of rat neocortex. The membrane propertics of rat neocortical layer I neurons, including the Cajal-Retzius cells, were very immature at birth. Rapid maturation occurred during the first two postnatal weeks, and adult- like properties were attained in the third postnatal weck. These results suggest that the postnatal development of intrinsic membrane properties of interneurons follows a time course similar to that described for pyramidal cells in neocortex (Burgard and Hablitz, 1993a) and hippocampus (Spigelman et al., 1992). The hallmark of mature interneurons, an ability to fire short-duration or fast APs without significant frequency adaptation, appears to be present from early stages in postnatal development. CajalRetzius cells were not different in their developmental pattern from other cell types in layer 1 .

\section{Development of passive membrane properties of layer I neurons}

During the first postnatal week, layer I neurons, including Cajal-Relzius cells, had relatively low RMPs, although the values observed are comparable with those reported for devel- 
oping thalamic neurons (Ramoa and McCormick, 1994). The mechanism underlying the low RMPs observed in immature neurons is not clear. It could represent physiological differences caused by alterations in expression of the ion channels and pumps responsible for generation and maintenance of the RMP. Bccausc the wholc-cell patch-recording configuration alters the intracellular ionic environment, the choice of the intracellular solution may be an important variable. Developmental differences in RMP were not observed in neocortical pyramidal cells when a $\mathrm{Cs}^{+}$-based intracellular pipette solution was used (Burgard and Hablitz, 1993b). Alternatively, using the whole-cell patch configuration for determining RMP may have caused an underestimate of the RMP for technical reasons. In the youngest cells, measured input resistances were in the gigaohm range. Seal resistances of even $5-10 \mathrm{G} \Omega$ could provide a pathway to ground for currents underlying generation of the RMP, causing an underestimate of the true RMP (Lynch and Barry, 1991). Conventional microelectrode recordings, which do not modify the intracellular environment, from rat neocortical pyramidal neurons have suggested that RMPs do not change with age (McCormick and Prince, 1987).

$R_{\mathrm{N}}$ in PN1-PN6 laycr I ncurons was very high, excecding $5000 \mathrm{M} \Omega$ in a few cases, and decreased rapidly during development. One possible explanation for this is an increase in membrane area. However, the somatic dimensions of CajalRetzius cells observed in the first postnatal week exceed those of other cell types in mature layer I (Zhou and Hablitz, 1995). Membranc time constants also were very long in layer I neurons during the first postnatal week, often exceeding 100 msec, and decreased significantly during the first two postnatal weeks. $R_{\mathrm{m}}$ was estimated to be $\sim 100 \mathrm{~K} \Omega / \mathrm{cm}^{2}$ in the very young cells and $\sim 50 \mathrm{~K} \Omega / \mathrm{cm}^{2}$ in relatively older cells, indicating a significant decrease in spccific membrane resistivity. Therefore, the rapid decrease in input resistance during the first two postnatal weeks likely is a combined effect of a progressive decrease in specific membrane resistivity and an increase in cell size. The decrease in $R_{\mathrm{n}}$ may reflect an increase in the expression of functional ion channels that are active around RMP. Such a mechanism would also explain why the decrease in $R_{\mathrm{N}}$ was steeper than in $\tau$.

The values for three key passive-membrane parameters of layer I neurons, $R_{\mathrm{N}}, R_{\mathrm{n}}$, and $\tau$, obtained in the present study are much higher than those obtained with conventional microelectrodes from rat neocortical pyramidal neurons at similar developmental ages (McCormick and Prince, 1987). Althuugh the difference in the input resistance is attributable in part to the comparatively large size of pyramidal neurons, the higher values of the three passive parameters in the present study may reflect a better cstimation because of the greatly reduced leak conductance introduced by patch recording. These higher values should provide more effective spatial and temporal integration of synaptic inputs in neurons during early development.

Cortical inhibition matures rapidly during the early postnatal period. GABA $_{A}$ receptor-mediated IPSPs can be recorded in PN4 rat neocortical neurons, indicating that inhibitory synapses formed by fast-spiking inhibitory cells already are functional (Luhmann and Prince, 1991). Most layer I neurons, including the Cajal-Retzius cells, are believed to be GABAergic (Gabbott and Somogyi, 1986; Imamoto et al., 1994; Prieto et al., $1994 a, b)$. It is likely that the development of membrane properties of layer I neurons reflects that of cortical inhibitory interneurons in general.

\section{Development of APs and repetitive firing properties of layer I neurons}

Our results indicate that a variety of ion channel types are already present at PN0. APs, although small in amplitude and long in duration, were present in all layer I neurons, including CajalRetzius cells, from the earliest times tested. The presence of an mAHP, attributable to activation of a $\mathrm{Ca}^{2+}$-mediated $\mathrm{K}^{+}$conductance (Schwindt el al., 1988), al PNO indicates that $\mathrm{Ca}^{2+}$ dependent $\mathrm{K}^{+}$channels also may be operational at this age. These findings are in general agreement with results from studies of neocortical pyramidal neurons (McCormick and Prince, 1987; Burgard and Hablitz, 1993). Such a synchronous development of voltage-gated ion channels is suited perfectly to balance excitation and inhibition in cerebral cortical networks from the earliest stages.

We found that in neocortical layer I neurons, AP waveforms matured rapidly in the first two postnatal weeks, and further changes were limited. In rat neocortical pyramidal neurons (McCormick and Prince, 1987) and CAl pyramidal neurons of the rat hippocampus (Spigelman et al., 1992), a similar rapid maturation also has been observed. In the ferret lateral geniculate nucleus, it has been shown recently that principal neurons also display substantial maturation in their electrophysiological properties during the first two postnatal weeks (Ramoa and McCormick, 1994). Taken together, these results suggest that in the central nervous system of small mammals AP waveforms mature rapidly in many types of neurons; therefore, coordinated activities in neuronal circuits may occur.

At all postnatal ages, layer I neurons were capable of repetitive firing in response to depolarizing current pulses, and this firing resembled the fast-spiking behavior of mature neurons. Frequency adaptation and SAIIPs were not observed. Ilowever, we found that the firing frequency attained in the very young cells was lower than in older cells. McCormick and Prince (1987) also reported that the slope of the current-frequency curve is less steep in young versus mature pyramidal cells. Although immature layer I neurons, particularly within the first 10 postnatal days, had a much higher input resistance than mature layer I neurons, the effect of the high input resistance appeared to be offset by a higher AP threshold and longer AP duration in immature cells. The higher threshold is attributable to the low density of sodium channels in immature cortical neurons and a depolarized shift in the activation threshold (Huguenand et al., 1988; Cummins et al., 1994), whereas a lower density of outward potassium currents in immature neurons contributes to the broad nature of the AP (Spigelman et al., 1992). The lower firing frequency attained by immature neurons may serve a protective function. preventing calcium overload caused by enhanced $\mathrm{Ca}^{2+}$ entry during prolonged APs.

Layer I neurons showed a rebound excitation during the first postnatal week. The slow rebound excitation could be caused by activation of a low-threshold $\mathrm{Ca}^{2+}$ current (Friedman and Gutnick, 1987), deactivation of $I_{\mathrm{h}}$ (Spain et al., 1991; Travagli and Gillis, 1994), or both. The full-size, fast APs triggered by the rebound depolarization were mediated via a TTX-sensitive mechanism. The ability to generate rebound APs was preserved or even enhanced later in development, perhaps because of the increased sodium channel density and a negative shift in activation kinetics (Huguenard et al., 1988; Cummins et al., 1994). 


\section{Changes in inward rectification during development}

In the first 10 postnatal days, layer I neurons, including CajalRetzius cells, showed very prominent inward rectification or sag. This became prominent around $-75 \mathrm{mV}$ and was blocked effectively by $1 \mathrm{~mm}$ extracellular $\mathrm{Cs}^{+}$, indicating that rectification may be mediated by an $I_{1}$-like current (McCormick and Pape, 1990).

If the current underlying production of the sag remained constant during devclopment, the decrease in $R_{\mathrm{N}}$ seen in older neurons could decrease the sag observed in voltage responses. However, in neurons of comparable input resistance, the sag was smaller in more mature cells. Therefore, a decrease in the cxpression of hyperpolarization-activated channels may be responsible, at least in part, for the decline of the sag with age. A similar, prominent, hyperpolarization-activated sag has been described in PN4-PN7 horizontal neurons of the stratum moleculare of rat dentate gyrus (von Haebler et al., 1993). The morphology of these dentate horizontal cells resembles that of the neocortical layer I horizontal Cajal-Retzius cells observed in the present study. The function of this hyperpolarization-activated current is not clear, but it is possible that in the very young cells with a high AP threshold, the current counterbalances any sustained hyperpolarizing influence, inhibiting discharge initiation.

\section{Membrane properties of Cajal-Retzius cells}

Because of a lack of neurophysiological data, the question of whether Cajal-Retzius cells are neurons has been raised on a few occasions (Wolff and Rickman, 1977; Edmunds and Parnavelas, 1982) (for detailed discussion, see Marin-Padilla, 1984). The present results show that Cajal-Retzius cells have basic membrane properties similar to other layer I neurons and can fire APs, establishing firmly the neuronal nature of Cajal-Retzius cells.

Based on anatomical data, the Cajal-Retzius neurons of the mammalian cerebral cortex have been reported to be the first neurons to differentiate fully and achieve functional maturity. This occurs before birth, whereas the smaller neurons in layer I are thought to be incorporated later during the course of cortical development (Bradford et al., 1978; Marin-Padilla, 1984, 1988; Chun and Shatz, 1989; Jacobson, 1991). This conclusion, although possibly valid for higher mammals with prolonged prenatal neurogenesis, does not appear to be true in lower mammals. The present physiological data indicate that Cajal-Retzius neurons do not show significantly earlier maturation of membrane or repetitive firing properties. This is in agreement the observation that in rat, $60 \%$ of Cajal-Retzius cells and $50 \%$ of relatively smaller layer I neurons are born on E14, indicating that the two cell types are born almost simultaneously (Bayer and Altman, 1990).

\section{Possible functional roles of layer I neurons in cortical development}

According to Marin-Padilla (1992), neocortical development begins with the establishment of the fetal layer $I$, and the formation of the cortical plate occurs within the fetal layer I. During development and maturation, pyramidal neurons retain and expand their original connections with layer $\mathbf{I}$, whereas other neuronal types lose these connections. Ogawa et al. (1995) have demonstrated recently the importance of Cajal-Retzius cells in cortical development by showing that interactions between Cajal-Retzius cells and migrating neurons are required for correct positioning.

It has been suggested that, in relatively simple neuronal systems, transient elevations of intracellular calcium are necessary for normal neuronal development (Spitzer et al., 1994). If a similar mechanism is used in the mammalian neocortex, the long-duration APs ohserved in immature layer I neurons could enhance $\mathrm{Ca}^{2+}$ entry into cells. In addition, in rat cerebellum, where $\mathrm{Ca}^{2+}$ is important for neuronal migration, a combination of voltage- and ligand-activated ion channels cooperatively regulates $\mathrm{Ca}^{2+}$ influx into migrating neurons (Rakic and Komuro, 1995). In rat neocortex, the development of GABAergic neurons begins very early, and GABAergic neurons with a morphology resembling Cajal-Retzius cells are observed on E15 in fetal layer I (Van Eden et al., 1989). In the hippocampus, where GABA can serve as an excitatory neurotransmitter during early development, activation of $\mathrm{GABA}_{\mathrm{A}}$ receptors during the first postnatal week induces a depolarization of immature CA3 pyramidal neurons associated with an increase in intracellular $\mathrm{Ca}^{2+}$ (Gairsa et al., 1995). If immature layer I neurons release GABA and/or other substances during early devclopment and incoming migrating ncurons respond with changes in intracellular $\mathrm{Ca}^{2+}$, layer I neurons may serve an inductive function in cortical development.

\section{REFERENCES}

Bayer SA, Altman J (1990) Development of layer I and the subplate in the rat neocortex. Exp Neurol 107:48-62.

Bradford R, Parmavelis JG, Lieberman AR (1978) Neurons in layer I of the developing occipital cortex of the rat. J Comp Neurol 176:121-132.

Burgard EC, Hablitz JJ (1993a) Developmental changes in NMDA and non-NMDA receptor-mediated synaptic potentials in rat neocortex. J Neurophysiol 69:230-240.

Burgard EC, Hablitz JJ (1993b) NMDA receptor-mediated components of miniature excitatory synaptic currents in developing rat neocortex. J Neurophysiol 70:1841-1852

Chun IIIM, Shatz C (1989) The carliest-generated neurons of the cat cerebral cortex: characterization by MAP2 and neurotransmitter immunohistochemistry during early fetal life. J Neurosci 9:1648-1667.

Connors BW, Gutnick MJ (1990) Intrinsic firing patterns of diverse neocortical neurons. Trends Neurosei 13:99-104

Cummins TR, Xia Y, Haddad GG (1994) Functional properties of rat and human neocortical vollage-sernsitive sodium currents. J Neurophysiol 71:1052-1064.

Del Rio JA, Soriano E, Ferrer I (1994) Development of GABAimmunoreactivity in the neocortex of the mouse. I Comp Neurol 326:501-526.

Edmunds SM, Parnavelas JG (1982) Retzius-Cajal cells: an ultrastructural study in the developing visual cortex of the rat. J Neurocytol $11: 427-446$.

Edwards FA, Konnerth A, Sakmann B, Takahashi T (1989) A thin slice preparation for patch clamp recordings from neurons of the mammalian central nervous system. Pflügers Arch 414:600-612.

Friedman A, Gutnick MJ (1987) Low-threshold calcium electrogenesis in neocortical neurons. Neurosci Lett 81:117-122.

Gabbott PLA, Somogyi P (1986) Quantitative distribution of GABAimmunoreactive neurons in the visual cortex (arca 17) of the cat. Exp Brain Res 61:323-331.

Gaiarsa J-L, McLean H, Congar P, Leinekugel X, Khazipov R, Tsecb V, Ben-Ari $Y$ (1995) Postnatal maturation of $\gamma$-aminobutyric acid $\mathrm{AB}^{-}$ mediated inhibition in the CA3 hippocampal region of the rat. $J$ Neurobiol 26:339-349.

Hamill OP, Marty A, Neher E, Sakmann B, Sigworth FJ (1981) Improved patch-clamp techniques for high-resolution current recording from cells and cell-free membrane patches. Pflïgers Arch 391:85-100.

Huguenard JR, Hamill OP, Prince DA (1988) Developmental changes in $\mathrm{Na}^{+}$conductances in rat neocortical neurons: appearance of a slowly inactivating component. J Neurophysiol 59:778 795.

Imamoto K, Karasawa N, Isomura G, Nagatsu I (1994) Cajal-Retzius neurons identified by GABA immunohistochemistry in layer I of the rat cerebral cortex. Neurosci Res 20:101-105.

Jacobson M (1991) Histogenesis and morphogenesis of cortical structures. In: Developmental neurobiology, 3rd Ed, pp 401-451. New York: Plenum.

Kasper EM, Larkman AU, Lubke J, Blakemore C (1994a) Pyramidal neurons in layer 5 of the rat visual cortex. I. Correlation among cell morphology, intrinsic electrophysiological properties, and axon targets. J Comp Neurol 339:459-474 
Kasper EM, Larkman AU, Lubke L, Blakemore C (1994b) Pyramidal neurons in layer 5 of the rat visual cortex. II. Development of electrophysiological properties. J Comp Neurol 339:475-494.

Kasper EM, Lubke L, Larkman AU, Blakemore C (1994c) Pyramidal neurons in layer 5 of the rat visual cortex. III. Differential maturation of axon targeting, dendritic morphology, and electrophysiological properties. J Comp Neurol 339:495-581.

Li JY, Schwark HD (1994) Distribution and proportions of GABAimmunoreactive neurons in cat primary somatosensory cortex. J Comp Neurol 343:335-361.

Lorenzon NM, Foehring RC (1993) The ontogeny of repetitive firing and its modulation by norepinephrine in rat neocortical neurons. Dev Brain Res 73:213-223.

Lynch JW, Barry PH (1991) Properties of transient $\mathrm{K}^{+}$currents and underlying single $\mathrm{K}^{+}$channels in rat olfactory receptor neurons. J Gen Physiol 97:1043-1072.

Luhmann HJ, Prince DA (1991) Postnatal maturation of the GABAergic system in rat neocortex. J Physiol (Lond) 65:247-263.

Marin-Padilla M (1984) Neurons of layer I: a development analysis. In: Cerebral cortex, Vol 1, Cellular components of the cerebral cortex (Peters A, Jones EG, eds), pp 447-478. New York: Plenum.

Marin-Padilla M (1988) Early ontogenesis of the human cerebral cortex. In: Cerebral cortex, Vol 7, Development and maturation of cerebral cortex (Peters A, Jones EG, eds), pp 1-34. New York: Plenum.

Marin-Padilla M (1992) Ontogenesis of the pyramidal cell of the mammalian neocortex and developmental cytoarchitectonics: a unifying theory. J Comp Neurol 321:223-240.

McCormick DA, Pape CH (1990) Properties of a hyperpolarizationactivated cation current and its role in rhythmic oscillation in thalamic relay neurons. J Physiol (Lond) 431:291-438.

McCormick DA, Prince DA (1987) Postnatal development of electrophysiological properties of rat cerebral cortical pyramidal neurons. J Physiol (Lond) 393:743-762.

McCormick DA, Connors BW, Lighthall JW, Prince DA (1985) Comparative electrophysiology of pyramidal and sparsely spiny stellate neurons of the neocortex. J Neurophysiol 54:782-806.

Meyer G, Ferres-Torres R (1984) Postnatal maturation of nonpyramidal neurons in the visual cortex of the cat. J Comp Neurol 228:226-244.

Miller M (1988) Development of projection and local circuit neurons in the neocortex. In: Cerebral cortex, Vol 7, Development and maturation of cerebral cortex (Peters A, Jones EG, eds), pp 133-168. New York: Plenum.

Ogawa M, Miyata T, Nakajima K, Yagyu K, Seike M, Ikenaka K, Yamamoto $\mathrm{H}$, Mikoshiba $\mathrm{K}$ (1995) The reeler gene-associated antigen on Cajal-Retzius neurons is a crucial molecule for laminar organization of cortical neurons. Neuron 14:899-912.

Parnavelas JG, Edmunds SM (1983) Further evidence that Retzius-Cajal cells transform to nonpyramidal neurons in developing rat visual cortex. J Neurocytol 12:863-871.

Paxinos G, Watson C (1986) The rat brain in stereotaxic coordinates, 2nd Ed. Sydney: Academic.

Peters A, Yilnaz E (1993) Neuronal organization in area 17 of cat visual cortex. Cerebral Cortex 3:49-68.

Pongracz F, Firestein S, Shepherd GM (1991) Electrotonic structure of olfactory sensory neurons analyzed by intracellular and whole cell patch techniques. J Neurophysiol 65:747-756.
Pricto JJ, Peterson BA, Winer JA (1994a) Morphology and spatial distribution of GABAcrgic neurons in cat primary auditory cortex (AI). $\mathrm{J}$ Comp Neurol 344:349-382.

Prieto JJ, Peterson BA, Winer IA (1994b) I Iaminar distribution and neuronal targets of GABAergic axonal terminals in cat primary auditory cortex (AI). J Comp Neurol 344:383-402.

Rakic P, Konuro H (1995) The role of receptor/channel activity in neuronal cell migration. J Neurobiol 26:299-315.

Rall W (1977) Core conductor theory and cable properties of neurons. In: Handbook of physiology, Vol 1, Sect 1, The nervous system, pp 39-97. Bethesda: American Physiological Society.

Ramoa AS, McCormick DA (1994) Developmental changes in electrophysiological properties of LGNd neurons during reorganization of retinogeniculate connections. J Neurosci 14:2089-2097.

Schwindt PC, Spain WJ, Foehring RC, Stafstrom CE, Chubb MC, Crill WE (1988) Multiple potassium conductances and their functions in neurons from cat sensorimotor cortex in vitro. J Neurophysiol $59: 424-449$

Spain WJ, Schwindt PC, Crill WE (1991) Post-inhibitory excitation and inhibition in layer $\mathrm{V}$ pyramidal neurones from cat sensorimotor cortex. J Physiol (Lond) 434:609-626.

Spigelman I, Zhang L, Carlen P (1992) Patch-clamp study of postnatal development of CA1 neurons in rat hippocampal slices: membrane excitability and $\mathrm{K}^{+}$current. J Neurophysiol 68:55-69.

Spitzer NC, Gu X, Olson E (1994) Action potentials, calcium transients and the control of differentiation of excitable cells. Curr Opin Neurobiol $4: 70-77$.

Spruston N, Johnston D (1992) Perforated patch-clamp analysis of the passive membrane properties of three classes of hippocampal neurons. J Neurophysiol 67:508-529.

Travagli RA, Gillis RA (1994) Hyperpolarization-activated currents $l_{\mathrm{H}}$ and $I_{\mathrm{KIR}}$ in rat dorsal motor nucleus of the vagus ncurons in vitro. $\mathrm{J}$ Neurophysiol 71:1308-1317.

Van Eden GC, Mrzljak L, Voorn P, Uylings HBM (1989) Prenatal development of GABAergic neurons in the neocortex of the rat. J Comp Neurol 289:213-227.

von Haebler D, Stabel J, Draguhn A, Heinemann U (1993) Properties of horizontal cells transiently appearing in the rat dentate gyrus during ontogenesis. Exp Brain Res 94:33-42.

Winer JA, Larue DT (1989) Populations of GABAcrgic neurons and axons in layer $I$ of rat auditory cortex. Neuroscience 33:499-515.

Wolff JR, Rickmann M (1977) Cytological characteristics of the early stages of the glial differentiation in neocortex. Folia Morphol (Warsz) 25:235-237.

Zhang L, Spigelman I, Carlen P (1991) Development of GABAmediated, chloride-dependent inhibition in CAl pyramidal ncurons of immature rat hippocampal slices. J Neurophysiol 444:25-49.

Zhou F-M, Hablitz JJ (1994) Morphological and electrophysiological properties of layer I neurons in rat neocortex. Soc Neurosci Abstr 20:1414.

Zhou F-M, Hablitz JJ (1995) Postnatal development of anatomical and electrophysiological properties of layer I neurons in rat neocortex. Soc Neurosci Abstr 21:2022. 